dr hab. Renata MARKS-BIELSKA

Wydział Nauk Ekonomicznych, Uniwersytet Warmińsko-Mazurski w Olsztynie

e-mail: renatam@uwm.edu.pl

mgr inż. Wojciech DERESZEWSKI

Gmina Kurzętnik

DOI: $10.15290 /$ oes.2018.01.91.10

\title{
SPRAWNOŚĆ INSTYTUCJONALNA W OBSZARZE SPOLECZNYM NA PRZYKłADZIE REALIZACJI POLITYKI MIESZKANIOWEJ PRZEZ GMINĘ KURZĘTNIK ${ }^{1}$
}

\begin{abstract}
Streszczenie
Celem przeprowadzonych analiz było zidentyfikowanie i ocena działań, które podejmują władze gminy Kurzętnik do kreowania pożądanej sytuacji mieszkaniowej na zarządzanym obszarze. Inicjatywy podejmowane w celu poprawy sytuacji mieszkaniowej obecnych i przyszłych mieszkańców gminy (m.in. sprzedaż uzbrojonych działek po preferencyjnych cenach dla rodzin korzystających z Programu 500+, z całej Polski, budowa osiedla mieszkaniowego przez Towarzystwo Budownictwa Społecznego), idące w parze z dynamicznym rozwojem przedsiębiorczości gospodarczej na analizowanym terenie, są przykładem sprawnego zarządzania z wykorzystaniem lokalnych zasobów i pojawiających się szans w ramach polityki na poziomie centralnym. Przedsięwzięcia te zasługują na pozytywną ocenę i mogą być wzorem dla innych gmin.
\end{abstract}

Słowa kluczowe: sprawność instytucjonalna, polityka mieszkaniowa, gmina

\section{INSTITUTIONAL EFFICIENCY IN THE SOCIAL SPHERE AS AN EXAMPLE OF HOUSING POLICY IMPLEMENTED BY THE KURZĘTNIK MUNICIPALITY}

\section{Summary}

The purpose of the analyzes was to identify and evaluate the actions taken by Kurzętnik's municipality to create the desired housing situation in the managed area. Initiatives undertaken to improve the housing situation of current and future residents of the municipality (eg sale of plots of land at preferential prices for families using the 500+ Program, from Poland as a whole, construction of a housing estate by the Society for Social Construction), coupled with dynamic development of entrepreneurship. The economics of the analyzed area are examples of efficient management, using local resources and emerging opportunities within central policy, deserve a positive rating and may be a model for other municipalities.

Key words: institutional efficiency, housing policy, municipality

JEL classification: H72, H41

\footnotetext{
${ }^{1}$ Gmina wiejska w województwie warmińsko-mazurskim, w powiecie nowomiejskim [szerzej: MarksBielska, 2016].
} 


\section{Wstęp}

Oceny efektów działalności samorządu terytorialnego są dokonywane na podstawie wielu kryteriów. Wynika to m.in. z różnorodności zadań, jakie obligatoryjnie i dobrowolnie podejmują kierujący gminą w celu jak najlepszego zaspokojenia potrzeb lokalnych społeczności, tworząc pożądany klimat społeczny. Jednym z kryteriów ewaluacji działań władz lokalnych jest coraz częściej kryterium sprawności. Odnosząc je do oceny funkcjonowania samorządu lokalnego, na potrzeby realizowanych badań ${ }^{2}$, zdefiniowano jako permanentna gotowość do kształtowania partnerskich relacji zarówno społecznych, jak i gospodarczych, jednocześnie zarówno z lokalną społecznością, jak i z przedsiębiorcami. Uwzględniana jest m.in. umiejętność formułowania celów, uzgadnianie ich z lokalną społecznościa, a także sprawne podejmowanie decyzji.

Sprawność instytucjonalna władz lokalnych jest ważnym czynnikiem analizowanym $\mathrm{w}$ aspekcie funkcjonowania samorządu lokalnego. Taki stan rzeczy wynika z interakcji tego obszaru aktywności z lokalnym rozwojem gospodarczym. Zwiększa się rola sprawnych instytucji samorządowych, których władze potrafią zidentyfikować pojawiające się w otoczeniu szanse i wykorzystać je do kształtowania rozwoju społeczno-gospodarczego. Najważniejszym obszarem działalności jednostek sektora publicznego jest świadczenie usług publicznych. Wymóg ich powszechnej dostępności sprawia, że nie powinny one podlegać regulacjom stricte rynkowym. Celem dostarczania usług społecznych jest maksymalizacja zysku społecznego, a nie osiąganie zysku finansowego [Biernacki i in., 2013, s. 162]. Implikuje to konieczność finansowania realizacji tego typu usług ze środków publicznych. Jednocześnie ograniczenia budżetowe, którymi objęty jest obecnie sektor administracji publicznej wymuszają aby świadczyć usługi o najwyższej jakości w sposób najbardziej efektywny ekonomicznie [Communication from the Commission, 2011].

Ze względu na fakt, że samorządy lokalne ze swej istoty i wypełnianych funkcji znajduja się blisko indywidualnych i społecznych potrzeb sa głównym partnerem państwa w realizacji celów rozwojowych. Spełniają ważną rolę w kreowaniu obywatelskiej aktywności i zaangażowania oraz w przeciwdziałaniu marginalizacji społecznej. Guzal-Dec [2015] dokonując przeglądu definicji polityki rozwoju lokalnego podkreśliła, że wśród szerokiego zakresu zadań publicznych, jakie realizuje samorząd terytorialny w celu zaspokojenia zbiorowych potrzeb mieszkańców, niezwykle istotne miejsce zajmuje m.in. cykl działań związanych z poprawą jakości życia

\footnotetext{
2 Podjęte w artykule rozważania odnoszą się do realizacji jednego z celów szczegółowych (identyfikacja czynników wpływających na sprawność instytucjonalną na poziomie lokalnym i jej ocena w badanych jednostkach) sformułowanych w ramach realizacji projektu badawczego Sprawność instytucjonalna vs. lokalny rozzój gospodarçy - caynniki ksztattujace i interakecje. Projekt został sfinansowany ze środków Narodowego Centrum Nauki przyznanych na podstawie decyzji numer DEC-2013/09/B/HS4/03039.

Głównym celem projektu była ocena sprawności instytucjonalnej w gminach i wskazanie jej związku z poziomem rozwoju gospodarczego. Wszystkie zidentyfikowane czynniki podzielono na pięć obszarów, w jakich samorządy lokalne wypełniają swoje zadania: gospodarczo-przestrzenny, finansowy, administracyjny, zarządzanie kadrami, w obszarze usług społeczno-kulturalno-oświatowych.
} 
członków wspólnoty samorządowej. Jednostki samorządu terytorialnego pozyskuja środki finansowe na inwestycje $\mathrm{w}$ infrastrukturę społeczną $\mathrm{i}$ komunalną, ponieważ bez nich nie są w stanie zaspokoić potrzeb mieszkańców gmin [Saar 2011].

Ważna rola, z punktu widzenia mieszkańców jednostek podziału terytorialnego w gospodarkach poszczególnych jednostek samorządu terytorialnego, przypada gminom, na terenie których odbywa się zaspokajanie potrzeb mieszkańców w zakresie gminnych dróg, ulic, mostów i organizacji ruchu drogowego. Ponadto gminy wykonują zadania w zakresie wodociagów, kanalizacji, utrzymania czystości i porządku, zaopatrzenia w energię cieplną i gaz, a także budownictwa mieszkaniowego [Szypliński 2008].

Jednym z elementów sprawnego zarządzania gminą jest tworzenie przyjaznego klimatu społecznego. Sa to działania podejmowane $\mathrm{w}$ ramach wyodrębnionego w badaniach obszaru, świadczonych przez gminę usług społeczno-kulturalno-oświatowych. Wśród tej grupy zadań ważne miejsce zajmuje polityka mieszkaniowa.

Posiadanie „dachu nad głową” stanowi podstawową ludzką potrzebę. Tę kwestię podkreśla się w licznych porozumieniach międzynarodowych, uznawanych przez Polskę. W Powszechnej Deklaracji Praw Człowieka uchwalonej przez ONZ w 1948 roku w art. 25 ust. 1 stwierdzono, że każdy człowiek ma prawo do stopy życiowej zapewniającej zdrowie i dobrobyt jemu oraz jego rodzinie, włączając $\mathrm{w}$ to m.in. „dach nad głowa”" [Muzioł-Więcławowicz 2015, s. 15-16].

Mieszkanie jest jednym z podstawowych dóbr egzystencjonalnych, zaspokaja elementarne potrzeby bytowe, daje poczucie bezpieczeństwa, kształtuje materialne i społeczne warunki życia człowieka. Cechy mieszkania, jego powierzchnia, układ, lokalizacja i otoczenie tworzą ramy egzystencji jednostki, rodziny, a nawet społeczeństwa. Godziwe warunki mieszkaniowe sprzyjają stabilizacji życiowej, pobudzają rozwój społeczno-gospodarczy i kulturalny [Szyszka 2008, s. 19].

Jednym z głównych mierników stosowanych w ocenie jakości mieszkania jest dostępność wystarczającej przestrzeni w lokalu. Według danych EUROSTAT w 2015 roku w przeludnionych mieszkaniach żyło około 16,7\% ludności UE-28. Najwyższe wskaźniki przeludnienia wśród państw członkowskich UE odnotowano w Rumunii $(49,7 \%)$ i w Polsce (43,4\%), natomiast wskaźniki przekraczające 50\% odnotowano w przypadku Serbii $(53,4 \%)$ i byłej jugosłowiańskiej republiki Macedonii $(51,1 \%)$. Również Turcja odnotowała stosunkowo wysoki wskánin przeludnienia (45,9\%, dane z 2013 roku). Najniższymi wskaźnikami przeludnienia charakteryzował się Cypr (1,4\%), Belgia $(1,6 \%)$, Holandia (3,3\%), Irlandia $(3,4 \%)$ i Malta $(3,5 \%)$.

W celu poprawy sytuacji mieszkaniowej ludności należy prowadzić aktywną politykę mieszkaniową, którą można rozpatrywać w węższym i szerszym ujęciu. W pierwszym z nich uznaje się, że jest to część polityki społecznej państwa. Wśród jej kompetencji znajduje się analiza i ocena problemu mieszkaniowego i wyrównywanie społecznych szans uzyskania mieszkania $z$ wykorzystaniem dostępnych narzędzi. Polityka mieszkaniowa uzupełnia (koryguje) rynek mieszkaniowy przez regulacje prawne, rozwiązania organizacyjne $\mathrm{i}$ instrumenty finansowe, poprawiając dostęp do mieszkań osobom narażonym na trudności w zaspokajaniu potrzeb 
mieszkaniowych ze względów społecznych i/lub ekonomicznych. Interwencja państwa polega na zapewnieniu funkcjonowania rynku mieszkaniowego w tych sferach, w których jest on w stanie zapewnić efektywna produkcję budowlano-montażowa, a także na korygowaniu ewentualnych jego niesprawności. Kwestią sporną pozostaje poziom ingerencji państwa w mechanizmy rynku nieruchomości mieszkaniowych, w tym dobór kryteriów oceny rozstrzygającej o podziale majątku trwałego między jednostki oraz gwarancję, że pewna część mieszkań stanowi społecznie pożądane dobra [Lis, 2011, s. 11].

W szerszym ujęciu, na politykę mieszkaniową składają się wszelkie działania państwa, które mają wpływ na funkcjonowanie rynku mieszkaniowego i na jego wynik (m.in. ilość, ceny i jakość zasobu mieszkaniowego). Szersza definicja wynika przede wszystkim ze złożoności rynku, poddanego oddziaływaniu podmiotów zarówno polityki makroekonomicznej, jak i licznych polityk sektorowych w wymiarze krajowym i międzynarodowym, centralnym i lokalnym [Muzioł-Więcławowicz, 2015, s. 18].

W Polce nie został wypracowany jeden spójny model prowadzenia polityki mieszkaniowej na szczeblu samorządowym. Polityka mieszkaniowa jest elementem zadań przypisanych samorządowi związanym z jego autonomicznością. Sposób, instrumenty zaangażowane do realizacji tej polityki zależą od przyjętej przez gminy strategii w tym obszarze, ich możliwości i potrzeb mieszkańców danego terytorium.

Rozwój mieszkalnictwa to w dłuższej perspektywie ważny element rozwoju kraju [Andrzejewski, 1997, s. 46]. W wielu teoriach ekonomicznych i socjologicznych dostrzec można zgodność odnośnie do przypisania sektorowi mieszkaniowemu niezwykłego znaczenia zarówno w życiu indywidualnym, społecznym, jak i państwowym. Znaczenie mieszkalnictwa zmusza do aktywnego zajęcia się tą problematyką nie tylko władze lokalne czy państwowe, lecz także instytucje międzynarodowe [Nykiel, 2009, s. 7].

Przyjęcie do Unii Europejskiej Polski i innych państw spowodowało, że problemy mieszkaniowe (szczególnie występujące w nowych krajach UE) zostały dostrzeżone przez władze wspólnoty i znalazły wyraz w kolejnych, przyjętych dokumentach. Szczególne znaczenie ma Europejska karta mieszkalnictwa. Nieco później zredagowano tzw. Kartę mieszkaniową opracowaną przez Komisję Rozwoju Regionalnego i przyjętą jako dokument roboczy przez intergrupę Parlamentu Europejskiego do spraw rozwoju miast i mieszkalnictwa w dniu 8 listopada 2006 roku. Końcowa część Karty zawiera propozycje odnośnie do kierunków działań Parlamentu Europejskiego w sprawach mieszkalnictwa, obejmując m.in. strukturalną pomoc finansową na wspieranie sektora mieszkaniowego w nowych krajach członkowskich [Nykiel 2009, s. 12].

Na poziomie kraju w Konstytucji Rzeczypospolitej Polskiej odnajdujemy zapis, że władze publiczne prowadza politykę sprzyjająca zaspokojeniu potrzeb mieszkaniowych obywateli, w szczególności przeciwdziałaja bezdomności, wspierają rozwój budownictwa socjalnego oraz popieraja działania obywateli zmierzające do uzyskania własnego mieszkania (art. 75. ust. 1). Konstytucja zapewnia również „nienaru- 
szalność mieszkania” oraz „wolność wyboru miejsca zamieszkania i pobytu” (art. 50 i 52.1).

Z badań Janusza [2010, s. 22] wynika, że kwestia mieszkaniowa stanowi jeden z problemów przestrzennego zróżnicowania rozwoju Polski. Mieszkańcy województw charakteryzujących się słabszą dynamiką rozwoju społeczno-gospodarczego stają w obliczu trudnych kwestii społecznych, które mogą przyczynić się do ich marginalizacji społeczno-ekonomicznej, czy sprzyjać procesom emigracyjnym. Na problemy związane m.in. z relatywnie gorszą infrastrukturą techniczna, niekorzystną sytuacją na rynku pracy nakładają się te związane z przeludnieniem mieszkań, złym stanem i wyposażeniem substancji mieszkaniowej.

Rozwiązanie kwestii mieszkaniowej jest złożone. Bazuje na społecznej wadze problemu mieszkaniowego oraz na wykorzystaniu mieszkalnictwa jako jednego z możliwych elementów programu stabilizowania i rozwoju gospodarki narodowej. Mieszkalnictwo może być w świadomy sposób wykorzystywane do wywoływania istotnych zmian po stronie produkcji i konsumpcji, zarówno w wartości rzeczowej, finansowej, jak i regulacyjnej gospodarki [Krakowińska 2008, s. 75].

Sytuacja związana z przeludnieniem mieszkań według danych EUROSTAT jest w Polsce niekorzystna. Ponaddwukrotnie więcej (44,8\%) osób w naszym kraju zamieszkuje przeludnione mieszkania w porównaniu do średniej UE-28, gdzie odsetek ten wynosi 17,3. Zajmujemy niechlubne trzecie miejsce (dane za 2013 roku) wśród krajów Unii Europejskiej (w odniesieniu do populacji ogółem, jak również ludności osiagającej poniżej $60 \%$ mediany dochodów ogółem - zagrożonej ubóstwem), a od lidera UE odnośnie najlepszej sytuacji mieszkaniowej - Belgii, która może poszczycić się tylko dwuprocentowym odsetkiem ludności zajmującej przeludnione mieszkania dzieli nas ponaddwudziestokrotna różnica.

O stopniu zaspokojenia potrzeb mieszkaniowych decyduje nie tylko liczba i wielkość mieszkań, ale także ich jakość. Za miernik wyrażający jakość mieszkań można przyjąć miernik bardziej złożony, a takim jest miernik poważnej deprywacji mieszkania wskazujący na brak w mieszkaniu odpowiedniego wyposażenia: bieżącej wody, toalety, a także mieszkania z przeciekającym dachem czy też niedostatecznie nasłonecznione. Również w tym przypadku Polska spośród krajów Unii Europejskiej wyróżnia się niekorzystnie. W 2014 roku 9,1\% polskich rodzin zamieszkiwało lokale zaliczane do grupy poważnej deprywacji. Warto jednak podkreślić, że w okresie 2005-2014 wskaźnik ten obniżył się z poziomu 29,7\%, a więc trzykrotnie [Kubów 2016, s. 54].

Wobec powyższego, prowadzenie racjonalnej polityki mieszkaniowej, wpisanej w szersze, długoterminowe cele polityki gospodarczej i społecznej jest w Polsce konieczne.

\section{Założenia metodyczne}

Celem przeprowadzonych analiz było zidentyfikowanie i ocena działań, które podejmują władze gminy do kreowania pożądanej sytuacji mieszkaniowej na zarządzanym obszarze. 
Analizy dokonano opierając się na dokumentach wewnętrznych Gminy Kurzętnik: Gminny Program „Kurzętnik - Mieszkanie+”; Program wsparcia budownictwa mieszkaniowego - Dobrze wykorzystaj „500+” - działki za pół ceny. Wykorzystano również wyniki badań ankietowych przeprowadzonych przez Zespół ds. Rozwoju Mieszkalnictwa w Urzędzie Gminy Kurzętnik. Badania dotyczyły oceny podjęcia programu społecznego

„Kurzętnik - Mieszkanie+”. Ankieta skierowana była do osób i rodzin o umiarkowanych dochodach i niezaspokojonych potrzebach mieszkaniowych. Celem było poznanie potrzeb mieszkaniowych, aby jak najlepiej dopasować ofertę, w ramach podejmowanego przedsięwzięcia inwestycyjnego do popytu na rynku. Zwrócono się do mieszkańców powiatu nowomiejskiego z prośbą o wypełnienie ankiety. W okresie od 8 września 2016 do 9 stycznia 2017 roku ankietę wypełniło 201 osób, $55 \%$ wypełniających stanowili mieszkańcy gminy Kurzętnik, 22\% - mieszkańcy gminy Nowe Miasto Lubawskie, a 23\% stanowili mieszkańcy innych gmin.

\section{Diagnoza sytuacji mieszkaniowej w gminie}

Gmina Kurzętnik posiada w swoim zasobie 19 lokali mieszkalnych. 11 lokali usytuowanych jest w budynkach wielorodzinnych. W latach 2015-2016 wyremontowano jeden $\mathrm{z}$ budynków mieszkalnych wielorodzinnych i oddano do użytku 5 lokali z przeznaczeniem pod najem. Lączna powierzchnia użytkowa lokali mieszkalnych wchodzących w skład mieszkaniowego zasobu gminy liczy $779,71 \mathrm{~m}^{2}$. Obecne zasoby mieszkaniowe nie zaspokajaja potrzeb nawet $\mathrm{w}$ minimalnym zakresie. W trosce o osoby napływowe, które będą chciały osiedlić się na terenie gminy, w związku z faktem dynamicznego rozwoju przedsiębiorczości na analizowanym terenie, władze gminy dostrzegaja konieczność prowadzenia aktywnej polityki mieszkaniowej.

W 2015 roku, według danych uzyskanych z Głównego Urzędu Statystycznego, do użytkowania w powiecie nowowiejskim oddano tylko 82 mieszkania (tabela 1). Był to bardzo niski wynik w stosunku do powiatów sąsiednich, województwa warmińsko-mazurskiego i kraju. Przedstawione dane utwierdzają w przekonaniu, że na terenie powiatu nowomiejskiego istnieje potrzeba rozwoju mieszkalnictwa wielorodzinnego. Według nieoficjalnych danych potencjalni nabywcy pochodzący z powiatu nowomiejskiego zakupuja lokale mieszkalne w sąsiednich powiatach (powiat iławski, olsztyński). Wiąże się to głównie z deficytem lokali mieszkalnych w powiecie nowomiejskim.

Diagnozę sytuacji mieszkaniowej przeprowadzono na podstawie wyników badań ankietowych. Wśród badanych było najwięcej w wieku od 31 do 40 lat $(36,3 \%)$. Prawie połowa (49,8\%) aktualnie zajmuje mieszkanie u rodziców, 22,9\% wynajmuje mieszkanie, $15,4 \%$ posiada własny dom, $8 \%$ posiada własne mieszkanie; $2 \%$ zajmuje mieszkania służbowe.

Najwięcej ankietowanych $(30,8 \%)$ zajmuje obecnie lokale o powierzchni od $36 \mathrm{~m}^{2}$ do $50 \mathrm{~m}^{2}$. Łączny przychód miesięczny w gospodarstwie domowym wynosi 
do $2000 \mathrm{zł} \mathrm{miesięcznie} \mathrm{w} \mathrm{przypadku} \mathrm{30 \%} \mathrm{ankietowanych,} \mathrm{2000-3000} \mathrm{zł} \mathrm{miesięcznie}$ -26,5\%, 3000-4000 zł miesięcznie - 28,5\%, powyżej 4000 zł miesięcznie - 15,0\%.

Jako czynniki mające bardzo duży wpływ przy wyborze mieszkania wskazywano jego cenę $(70,5 \%)$, lokalizację $(40,0 \%)$, powierzchnię $(37,7 \%)$, dostępność parkingów $(34,5 \%)$, oddzielną kuchnię $(37,7 \%)$, standard mieszkania (38,3\%). Dla 39,4\% badanych czynnikiem, który nie ma żadnego wpływu przy wyborze mieszkania jest wyposażenie w windę.

TABELA 1.

Mieszkania oddane do użytkowania w powiecie nowomiejskim a tle powiatów sąsiednich, województwa i kraju (2015)

\begin{tabular}{|l|c|c|c|}
\hline $\begin{array}{c}\text { Jednostka } \\
\text { administracyjna }\end{array}$ & $\begin{array}{c}\text { Liczba } \\
\text { mieszkańców }\end{array}$ & $\begin{array}{c}\text { Liczba mieszkań } \\
\text { oddanych do } \\
\text { użytkowania }\end{array}$ & Współczynnik* \\
\hline Powiat nowomiejski & 44291 & 82 & 1,8 \\
\hline Powiat iławski & 93052 & 348 & 3,7 \\
\hline Powiat ostródzki & 106442 & 307 & 2,8 \\
\hline Miasto olsztyn & 173831 & 700 & 4,0 \\
\hline Powiat olsztyński & 123049 & 856 & 6,9 \\
\hline Powiat działdowski & 66286 & 239 & 3,6 \\
\hline $\begin{array}{l}\text { Województwo warmińsko- } \\
\text {-mazurskie }\end{array}$ & 1440000 & 4310 & 3,0 \\
\hline Polska & 38437000 & 147711 & 3,8 \\
\hline
\end{tabular}

* Mieszkania oddane do użytkowania na 1000 mieszkańców

Źródło: opracowanie własne podstawie danych GUS (www.stat.gov.pl)

Jako główny motyw zakupu mieszkania wskazywano usamodzielnienie się $(35,5 \%)$, zamianę wynajmowanego mieszkania na własne (17,3\%) oraz zakup mieszkania jako inwestycję dla dzieci $(15,2 \%)$. Motywami mniej istotnymi okazały się: zmiana miejsca zamieszkania $(9,1 \%)$, zamiana mieszkania na większe $(8,1 \%)$, zmiana lokalizacji na lepsza $(7,1 \%)$, podwyższenie standardu $(6,6 \%)$.

Większość ankietowanych (57,0\%) wybrała mieszkanie 3-pokojowe, które spełni ich oczekiwania, 25,0\% wypełniających wybrało mieszkanie 2-pokojowe, $16 \%$ wypełniających wybrało opcję mieszkania większego niż 3-pokojowe, jedynie $2 \%$ wypełniających jest zainteresowanych mieszkaniem 1-pokojowym. 81,5\% biorących udział w ankiecie jest zainteresowanych mieszkaniem o powierzchni od 46 do $55 \mathrm{~m}^{2}$ i większym.

Jako najistotniejsze elementy otoczenia/sąsiedztwa wskazywano dostępność obiektów infrastruktury społecznej takie jak: szkoły, przedszkola, ośrodki zdrowia $(39,2 \%)$, bliskość terenów zielonych, rekreacyjnych $(31,2 \%)$, bezpieczeństwo $(16,6 \%)$, dostępność komunikacyjną - drogi, przystanki (9\%), dostępność placówek handlowych $(4 \%)$. 


\section{Polityka mieszkaniowa na poziomie gminy}

W gminach politykę mieszkaniową definiuje się najczęściej zgodnie z ustawą o ochronie praw lokatorów, a jako najważniejszy uznaje się art. 4 ust. 1 ustawy dotyczący obowiązku tworzenia warunków do zaspokajania potrzeb mieszkaniowych wspólnoty samorządowej, zapewnienia lokali socjalnych i zamiennych. Generalnie dotyczy to zaspokojenia potrzeb mieszkaniowych gospodarstw o niskich dochodach.

Politykę mieszkaniowa gminy można rozpatrywać w co najmniej trzech aspektach. W ujęciu ekonomicznym uwzględnia się ustalenie potrzeb mieszkaniowych i poziomu ich zaspokojenia przy możliwie najlepszym wykorzystaniu dostępnych środków. Problematyka społeczna dotyczy szczególnie warunków mieszkaniowych ludności. Związki gospodarki mieszkaniowej z budownictwem, działalnością remontową oraz procesami przebudowy i modernizacji zasobów mieszkaniowych dotyczą aspektów technicznych.

Kompetencje w zakresie polityki mieszkaniowej posiadaja władze krajowe (rządy) oraz władze samorządowe szczebla lokalnego. W większości krajów europejskich zadania w zakresie pomocy mieszkaniowej wykonują samorządy lokalne, przy wsparciu władz centralnych. Obserwuje się, że władze gmin coraz rzadziej angażują się $\mathrm{w}$ budowę i zarządzanie zasobami mieszkaniowymi bezpośrednio. Powierzają te zadania partnerom spoza sektora finansów publicznych. W Polsce są nimi Towarzystwa Budownictwa Społecznego (TBS) lub też inne gminne spółki prawa handlowego. Zadania te mogą spełniać częściowo podmioty zewnętrzne.

Niedobór środków publicznych na potrzeby mieszkaniowe kieruje uwagę decydentów na sektor prywatny. Jedną z form wykonywania zadań jest partnerstwo publiczno-prywatne (PPP), ale możliwe są też inne formy współpracy, m.in. ulgi podatkowe dla inwestorów mieszkaniowych, agencje pośredniczące w wynajmowaniu mieszkań najemcom socjalnym.

W Polsce do zadań gmin w zakresie mieszkalnictwa należy zapewnianie mieszkań gospodarstwom o niskich dochodach, dostarczanie lokali socjalnych i zamiennych, dostarczanie pomieszczeń tymczasowych oraz wypłata dodatków mieszkaniowych. Lokale socjalne przysługuja osobom i rodzinom o bardzo niskich dochodach oraz większości osób, wobec których sądownie orzeczono eksmisję z mieszkania. Mają one zazwyczaj niski standard i niewielką powierzchnię. W ramach polityki społecznej gminy angażują się również w zapewnianie schronienia osobom bezdomnym [Muzioł-Więcławowicz 2015].

Za adekwatne do osiagania pożądanych w zakresie polityki mieszkaniowej celów, należy uznać zasady, którymi trzeba się kierować prowadząc racjonalną politykę mieszkaniową [Borek 2016]:

- celowość - pomoc powinna być skierowana do osób najbardziej potrzebujących,

- przejrzystość - polityka dotacyjna musi być przejrzysta i zrozumiała dla wszystkich, 
- sprawiedliwość - powinna być to polityka sprawiedliwa dla większości uczestników,

- maksymalne wykorzystanie środków sektora prywatnego - wybranie takich rozwiązań, które pozwola na optymalne wykorzystanie środków gospodarstw domowych i sektora prywatnego - większość wydatków na mieszkalnictwo powinno pochodzić ze środków prywatnych,

- polityka zachęcania i podtrzymywania rozwoju prywatnego rynku - taka polityka, która nie konkuruje z mechanizmami rynkowymi, przede wszystkim z komercyjnymi możliwościami finansowania inwestycji mieszkaniowych, a jest w stosunku do nich komplementarna,

- efektywność ekonomiczna - przez osiaganie rezultatów przy minimalnych wydatkach budżetu

- $\quad$ sprawność administracji - minimalizacja czasu i kosztów administracyjnych.

W gminie Kurzętnik podejmowane sa działania prospołeczne, zgodne z obecna polityką Rządu Rzeczypospolitej Polskiej. Na poziomie kraju realizowany jest bowiem Narodowy Program Mieszkaniowy (uchwała nr 115/2016 przyjęta przez rząd 27 września 2016 roku) określający politykę mieszkaniową państwa w horyzoncie średniookresowym. Polityka mieszkaniowa wprowadza rozwiązania zwiększające dostępność mieszkań, zwłaszcza dla rodzin o przeciętnych i niskich dochodach. Rząd przyjął Narodowy Program Mieszkaniowy 27 września 2016 r. (uchwała nr 115/2016). Podstawowe rozwiązania wdrażające nowa politykę mieszkaniową są określane w pakiecie Mieszkanie+, opartym na trzech filarach mających pomóc stworzyć w Polsce ofertę mieszkaniową kierowaną do wszystkich gospodarstw domowych. Te 3 filary to: 1) dostępne budownictwo na wynajem na gruntach Skarbu Państwa, 2) społeczne budownictwo czynszowe, 2) pomoc w ponoszeniu wydatków mieszkaniowych w pierwszych latach najmu mieszkania. Mieszkanie+ to nowy program budowy dostępnych mieszkań dla rodzin w ramach systemu najmu z opcja docelowej własności, realizowany przy wykorzystaniu finansowania rynkowego. W tym celu zostaną wykorzystane nieruchomości Skarbu Państwa oraz instrumenty rynkowe, w szczególności zaś formuła funduszu inwestycyjnego zamkniętego. Mieszkanie+ ma przyczynić się do obniżania cen mieszkań. Program Mieszkanie+ to działanie realizowane we współpracy z samorządami, a także innymi podmiotami, w tym spółkami Skarbu Państwa.

Gminę Kurzętnik można uznać za lidera aktywnego podejścia do lokalnej polityki mieszkaniowej. Ze względu na fakt, że lokale mieszkalne są dobrem o charakterze niezbędnym i podstawowym dla ludzi, zadanie mające na celu tworzenie mieszkań i zaspokajanie potrzeb społeczeństwa $\mathrm{w}$ tym zakresie uznano za priorytetowe i już 2 czerwcu 2016 roku Rada Gminy Kurzętnik podjęła w drodze Uchwały nr XXI/183/2016 Program wsparcia budownictwa mieszkaniowego dobrze wykorzystaj $500+-$ działki za pół ceny. Głównym celem programu jest przede wszystkim rozwój mieszkalnictwa na terenie gminy, podjęcie przyszłościowej inwestycji dla dzieci z rodzin korzystających z rządowego Programu $500+$, wzrostu urodzeń w gminie Kurzętnik oraz zwiększenie dostępności działek budowlanych. Działki przeznaczone do sprzedaży w ramach programu w planie zagospodarowania 
przestrzennego przeznaczone sa pod zabudowę mieszkalną jednorodzinną. Są uzbrojone w sieć wodociagową i elektryczną. Władze lokalne gminy Kurzętnik przeznaczyły do sprzedaży 33 działki, które cieszyły się dużym zainteresowaniem wśród nabywców.

Nabywcom działek w ramach programu została udzielona bonifikata w wysokości $50 \%$ ceny podstawowej działki. Władze samorządu lokalnego określiły również warunki, które musi spełnić przyszły nabywca działek sprzedawanych w ramach omawianego programu. Warunkiem jest posiadanie decyzji o przyznaniu świadczenia wychowawczego z programu Rodzina 500+ oraz zobowiązanie dotyczące braku możliwości przeniesienia własności działki przez 10 lat. W zakresie realizacji programu samorząd prowadzi również rozmowy z właścicielami prywatnych gruntów na swoim terenie, żeby na zasadzie partnerstwa przyłączyli się do inicjatywy gminy. Właściciele prywatni chętni do współpracy w programie mogą zaoferować 220 działek. Ponadto gmina przygotowuje do sprzedaży w ramach programu kolejnych 49 działek.

Gmina Kurzętnik wyprzedzając rządowy program Mieszkanie+ opracowała własny program wspierający rozwój budownictwa wielorodzinnego, pn. „KurzętnikMieszkanie+". Program przyjęła Rada Gminy Kurzętnik w dniu 13 września 2016 roku Uchwała nr XIV/238/16.

Kontynuacja działań władz samorządu było powołanie na podstawie Uchwały nr XXV/243/16 Rady Gminy Kurzętnik z dnia 13 września 2016 roku Towarzystwa Budownictwa Społecznego Sp. z o.o. Jedynym udziałowcem w spółce jest Gmina Kurzętnik (100\% udziałów). Przedmiotem działalności TBS jest budowanie domów mieszkalnych i ich eksploatacja na zasadach najmu oraz zarządzanie zasobem lokalowym, budynkami i terenami stanowiącymi własność gminy Kurzętnik.

Zgodnie z założeniami polityki mieszkaniowej gminy Kurzętnik zaspokajanie potrzeb mieszkaniowych powinno uwzględniać w pierwszej kolejności uwarunkowania ekonomiczne i społeczne lokalnej społeczności. Przeprowadzona analiza poziomu zamożności społeczeństwa oraz potrzeby polityki prorodzinnej gminy dały podstawę do określenia priorytetów i celów stawianych w kierunku rozwoju mieszkalnictwa wielorodzinnego.

Towarzystwo Budownictwa Społecznego Kurzętnik Sp. z o.o. jest właścicielem gruntu położonego w bliskiej odległości od istniejących placówek oświatowych, służby zdrowia oraz terenów inwestycyjnych Specjalnej Strefy Ekonomicznej S.A. w Nielbarku. Teren planowanej inwestycji znajduje się w bezpośrednim sąsiedztwie kompleksów leśnych i terenów rekreacyjnych doliny rzeki Drwęcy oraz oświetlonych ciagów pieszo-rowerowych. Dodatkowo, w najbliższych latach władze samorządowe planują na sąsiednim gruncie budowę zespołu przedszkolno-żłobkowego dla 300 dzieci. Kompleksowa realizacja inwestycji stwarza warunki dla powstania osiedla mieszkaniowego z nowoczesnym zapleczem oświatowo-rekreacyjnym o wysokiej jakości urbanistycznej.

W latach 2016-2020 planowana jest budowa 5 budynków wielorodzinnych (160 lokali mieszkalnych). Oferta mieszkań sformułowana została w dwóch wersjach (standard podstawowy i rozszerzony). Różnia się one nie tylko jakością użytych 
materiałów, ale również zakresem wykończenia. Istnieje możliwość uzupełnienia poszczególnych standardów o dodatkowe elementy na podstawie odrębnej umowy. Koszt wykończenia w standardzie podstawowym lub rozszerzonym jest składowa ceny mieszkania i jest finansowany przez TBS Kurzętnik, co stanowi jedną z zalet wyboru opcji wykończenia mieszkania „pod klucz”.

Elementy, które w istotny sposób wpływają na cenę mieszkań to m.in. koszt zakupu ziemi pod inwestycję, projekt budowlany, koszt nadzorów budowlanych na etapie realizacji przedsięwzięcia, jak również, co istotne przy komercyjnym charakterze inwestycji - zysk dewelopera. Elementy te maja bardzo istotny wpływ na finalną wartość $1 \mathrm{~m}^{2}$ powierzchni użytkowej lokalu mieszkalnego, który trafia na rynek nieruchomości.

W związku z faktem, że inwestycja TBS Kurzętnik jest prowadzona na gruncie własnym, na cenę mieszkań nie będzie miał też wpływu zysk developera (który nie będzie osiągany $z$ tej inwestycji), spółka jest w stanie zaoferować nabywcom lokal o wysokim standardzie, położony na bardzo atrakcyjnym terenie, za kwotę $2890 \mathrm{zł}$ brutto za $\mathrm{m}^{2}$.

\section{Podsumowanie}

Podstawowym celem działań podejmowanych przez zarządzających gminą jest rozwój społeczno-gospodarczy. Droga realizacji tego celu jest $\mathrm{m}$. in. zaspokajanie potrzeb mieszkańców poszczególnych jednostek samorządu terytorialnego. Jedną z elementarnych potrzeb jest poprawa warunków życia, zaspokajana przez dostęp do miejsc pracy oraz warunków mieszkaniowych zgodnych z możliwościami finansowymi i preferencjami. Prowadząc do zaspokojenia wymienionych potrzeb władze gminy moga wspierać rozwój przez dążenie do zapewnienia jak najlepszej atrakcyjności inwestycyjnej i wspieranie budownictwa. Zaspokojenie tych potrzeb wiąże się z posiadaniem odpowiedniego zasobu gruntów (inwestycyjnych i z możliwością zabudowy). Wszelkie działania władz gminy w tym zakresie muszą być prowadzone w sposób społecznie i ekonomicznie efektywny.

Przytoczone dane przekonuja, że sytuacja mieszkaniowa w Polsce wymaga koniecznych zmian. Prowadzona do tej pory polityka mieszkaniowa na różnych szczeblach nie przyniosła zamierzonych efektów. Wprowadzane zmiany, w tym szczególne te na poziomie lokalnym powinny być ukierunkowane na potrzeby społeczne, a prowadzone inwestycje i instrumenty realizowania polityki mieszkaniowej muszą być efektywne ekonomicznie.

Optymistyczne jest, że istnieją pozytywne przykłady, które dają wymierne efekty prowadzenia polityki mieszkaniowej na poziomie gminy. Przykładem dobrych praktyk $\mathrm{w}$ analizowanym zakresie jest polityka mieszkaniowa realizowana $\mathrm{w}$ gminie Kurzętnik. Posiadając określone zasoby gruntów, które mogą być wykorzystane pod budownictwo mieszkaniowe, dysponując dobrze przygotowaną infrastrukturą techniczną i społeczna, zarządzający gmina podjęli działania zmierzające do poprawy sytuacji mieszkaniowej obecnych i przyszłych mieszkańców gminy. Propozycja, z jaką wyszedł samorząd lokalny do społeczności (sprzedaż działek po preferen- 
cyjnych cenach dla rodzin korzystających z Programu 500+, z całej Polski) może również pomóc $\mathrm{w}$ racjonalnym wykorzystaniu środków pochodzących z wymienionego programu.

Polityka mieszkaniowa zmierzająca do zaspokojenia potrzeb społeczności lokalnej w analizowanym zakresie jest prowadzona dwutorowo - w kierunku rozwoju budownictwa jedno- i wielorodzinnego, a także lokali mieszkalnych $\mathrm{w}$ ramach Towarzystwa Budownictwa Społecznego. Ważne jest, że zainteresowani poprawa warunków mieszkaniowych w ramach TBS partycypują w kosztach tego przedsięwzięcia, według indywidualnych możliwości finansowych.

Gmina Kurzętnik to miejsce, gdzie obecni i przyszli przedsiębiorcy mają dogodne warunki do prowadzenia działalności gospodarczej (m. in. w ramach preferencji specjalnej strefy ekonomicznej i przychylnego prawa lokalnego). Zarządzający gminą dostrzegaja potrzebę sprawnego zarządzania we wszystkich $\mathrm{z}$ wyodrębnionych w badaniach w ramach projektu naukowego obszarach, w jakich samorządy lokalne wypełniaja swoje zadania: gospodarczo-przestrzenny, finansowy, administracyjny, zarządzania kadrami, w obszarze usług społeczno-kulturalno-oświatowych. Zauważalna jest, zgodna z zaproponowaną definicją sprawności instytucjonalnej, nieustająca gotowość do kształtowania partnerskich relacji gospodarczych i społecznych z lokalną społecznością i z przedsiębiorcami, formułowanie krótko- i długookresowych celów, uzgadnianie ich z lokalną społecznością, sprawne podejmowanie decyzji i realizacja celów.

W niniejszym opracowaniu przedmiotem analizy był jeden z elementów realizowany w ramach usług społecznych - aktywna polityka mieszkaniowa. Ze względu na specyfikę gminy i jej prorozwojowy charakter zarządzający uznali za zasadne, aby podjąć działania w zakresie realizacji inwestycji dotyczącej budowy budynków mieszkalnych wielorodzinnych $\mathrm{z}$ jednoczesnym zapewnieniem edukacji żłobkowej i przedszkolnej. Stworzenie najpierw miejsc pracy, a następnie dobrych warunków do życia może przyczynić się do przyciagnięcia wykwalifikowanej kadry pracowniczej, czego oczekują władze lokalne, przedsiębiorcy i potencjalni inwestorzy.

\section{Literatura}

Andrzejewski A., 1997, Polityka mieszkaniowa, Wyd. PWE, Warszawa.

Biernacki M., Ejsmont W., Lyko J., Maciuk A., 2013, Proposycja syntetycznego miernika

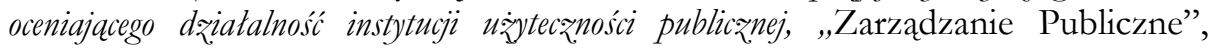
nr 2(22), DOI: 10.4467/20843968ZP.13.014.1188.

Borek A., 2016, Gminna polityka mieszkaniowa http://www.wspolnotamieszkaniowa. pl/aktualnosci/gminna-polityka-mieszkaniowa/899.html [data wejścia: 20.01.2017].

Communication from the Commission to the European Parliament, the Council, the European Economic and Social Committee and the Committee of the Regions. A Quality Framework for Services of General Interest in Europe (COM(2011) 900 final). 
Dokumenty wewnętrzne gminy Kurzętnik: Gminny Program „Kurẓ̨tnik - Mieszkanie+ "; Program wsparcia budownictwa mieszkaniowego - Dobrze wykoraystaj „500+” dziatki za pót ceny.

Gagacka M., 2016, Rola samorzadón lokalnych w przecindziałaniu procesom marginalizacji społecznej, [w:] Jakosíc sycia w regionie, J. Karwowski (red.), Uniwersytet Szczeciński, Szczecin.

Guzal-Dec D., 2015, Samorzad gminny w kreowaniu zrównoważonego roz̧woju obszarów prayrodniczo cennych województwa lubelskiego, PWSZ, Biała Podlaska.

Janusz M., 2010, Sytuacja mieszkaniowa w miastach na prawach powiatu woj. warminiskomazurskiego w latach 2005-2008, „Polityka Społeczna”, nr 11-12.

Krakowińska E., 2008, Miesそkalnictwo jako dobro wiodace w gospodarce, „Prace i Materiały - Wydział Zarządzania UW", nr 1.

Kubów A., 2016, Sytuacja rodżin i polityka rodzinna w Polsce po dekadzie çৃonkostwa w Unii Europejskiej, „Prace Naukowe Uniwersytetu Ekonomicznego we Wrocławiu", nr 438.

Lis P., 2016, Cele i instrumenty spolecznej polityki mieszkaniowej, [w:] Wspótczesne przemiany środowiska mieszkeaniowego - mybrane problemy, J. Dzieciuchowicz (red.). Wydawnictwo Uniwersytetu Lódzkiego, Łódź.

Marks-Bielska R., Wojarska M., Lizińska W., Babuchowska K., 2016, Sprawność instytucjonalna a lokalny rozwój gospodarcsy - stadium praypadku gminy Kurz̨etnik, [w:] Pržedsiębiorczość gospodarcza a rozwój lokalny, R. Marks-Bielska (red.), Informatyczny Ekspert Sp. z o.o., Olsztyn.

Muzioł-Więcławowicz A., 2015, Problemy mieszkaniowe Polaków a polska polityka mieszkaniowa, [w:] Mieszkalnictwo w Polsce. Analiza wybranych obszarów polityki mieszkaniowej, M. Salamon i A. Muzioł-Więcławowicz (red.), Habitat for Humanity, Warszawa.

Nykiel L., 2009, Funkcie i rola państwa na rynku mieszkanionym, „Studia i Materiały Towarzystwa Naukowego Nieruchomości”, t. 7, nr 4.

Saar M. A., 2011, Jak samorzady lokalne moga wspierać rozwój przedsiębiorczości?, CeDeWu.pl „Wydawnictwa Fachowe”, Warszawa.

Szypliński M., 2008, Prawne formy realizacji zadań gospodarczych i spotecznych samorzadu terytorialnego, Dom Organizatora, Toruń.

Szyszka M., 2008, Polityka rodrinna w Polsce 1990-2004, Wyd. KUL, Lublin. 